\title{
The use of pesticides in Polish agriculture after integrated pest management (IPM) implementation
}

\author{
Arkadiusz Piwowar ${ }^{1}$ \\ Received: 20 July 2020 / Accepted: 28 December 2020 / Published online: 25 January 2021 \\ (C) The Author(s) 2021, corrected publication 2021
}

\begin{abstract}
The aim of the conducted study was to characterize the attitudes and practices of Polish farmers in the area of performing chemical plant protection treatments. A particular attention was paid to identifying the relationship between the direction of changes in the volume of chemical plant protection product consumption and selected attributes of farms. The main time range of the analyses covered the period of 2013-2017. Statistical data and results of representative surveys carried out on a sample of 1101 farms in Poland were used in the research process. Due to the large number of variants of the analysed variables, a multiple correspondence analysis was used, which made it possible to determine the correlation between the examined features (direction of changes in pesticide use relative to the farm area, economic size of the farm and location of the farm). Statistical analysis showed the existence of strong relationships between the physical (1) and economic (2) size of farms and the direction of changes in pesticide consumption ((1) $\varphi^{2}=0.0907$; (2) $\left.\varphi^{2}=0.1141\right)$ ). According to empirical studies, the reduction of pesticide consumption took place mainly on the smallest farms. The implementation of the integrated plant protection directive has not resulted in significant changes in the form of reduced pesticide use in large-scale field crops. This raises the need to modify the strategy and model of crop protection in large-scale field crops in Poland.
\end{abstract}

Keywords Chemical plant protection $\cdot$ Integrated pest management (IPM) $\cdot$ Multiple correspondence analysis (MPA)

\section{Introduction}

Plant protection is an interdisciplinary field of knowledge, research and economic practice. Chemical plant protection is an integral part of effective, conventional and integrated farming (Aktar et al. 2009; Leong et al. 2020). This is because pesticides make it possible to increase crop yields by reducing losses due to plant diseases, foraging insects that feed on these plants, etc. The popularity of pesticide use in farming is due to the fact that chemical plant protection is relatively cheap and effective (Lechenet et al. 2017; Bernhardt et al. 2017; Hedlund et al. 2020). Much is expected after the development of biological methods in the field of plant protection, but still the effectiveness

The original online version of this article was revised: The y-axis legend of Figure 6 is cut-off in the original published paper.

Responsible Editor: Baojing Gu

Arkadiusz Piwowar

arkadiusz.piwowar@ue.wroc.pl

1 Wroclaw University of Economics and Business, Komandorska Street 118/120, 53-345 Wrocław, Poland of most bio-pesticides is much lower than that of chemicals (Compant et al. 2005). Moreover, the expensive registration procedure and the more difficult and troublesome application of bio-pesticides do not support the dynamics of changes on the global market of plant protection products (Pavela and Benelli 2016; Bruce et al. 2017; Kerr and Bullard 2020; Isman 2020).

On the other hand, excessive use of pesticides is connected with environmental and health risks and also leads to the development of resistance to pesticides (Schäfer et al. 2007; Jallow et al. 2017; Fletcher et al. 2020; Serrano et al. 2020). The introduction of chemical protection agents into agrocenoses violates the ecological stability of the environment and has a direct impact on the biodiversity of ecosystems (Pimentel et al. 1993; Gagic et al. 2017; Klich et al. 2020). The chemical methods of plant protection have a negative effect on earthworm populations (Bart et al. 2018; Treder et al. 2020). It should be emphasized, however, that the most harmful products are systematically withdrawn from use (Lamichhane et al. 2016). Currently produced agrochemicals, including plant protection products, are innovative preparations in all aspects. Research and development works are constantly being carried out on optimizing the effectiveness and selectivity of the preparations and minimizing 
the impact of pesticide application on the health and safety of humans and animals (Liu and Huang 2013; Kumar et al. 2019; Mancini et al. 2019). An important direction of the research are pro-ecological technologies and techniques for the production of plant protection products based on immobilization processes, using bio-renewable resources, etc. (Włodarczyk and Siwek 2017; Ndao et al. 2020). Progress in toxicology, chemistry and biotechnology is being used (Chhipa 2017; Hazra and Purkait 2019; Slattery et al. 2019). Despite this, there is still discussion about the harmfulness of, e.g. one of the most popular herbicides in the world, whose active substance is glyphosate ([N-(phosphonomethyl) glycine]) (Silva et al. 2018; Myers et al. 2016; Benbrook 2019; Padilla and Selim 2020; Beckie et al. 2020; Kudsk and Mathiassen 2020; Rogacz et al. 2020). Generally, a lot of original publications by authors from various scientific and research centres as well as literature reviews indicate a relationship between the use of plant protection products and the increased risk of developmental disorders, cancer diseases, etc. (Tayour et al. 2019; Huang et al. 2019; Han et al. 2019; Sabarwal et al. 2018; Zeng et al. 2017; Narayan et al. 2017; Egbuna et al. 2020). Many papers also concern the safety of performing chemical plant protection treatments, including operator safety (Matthews 2008; Feola and Binder 2010; Damalas and Abdollahzadeh 2016). Declines in the number and diversity of insects have focused attention on the role of pesticides and their impact on health, including honeybees (Zawislak et al. 2019; Prado et al. 2019; Uhl and Brühl 2019; Crenna et al. 2020). A lot of studies show that bees are exposed to pesticides, although there are differences in sensitivity between bee species (Hladik et al. 2016; Woodcock et al. 2017; Arena and Sgolastra 2014). There is also the problem of residues and secondary emissions of pesticides with historical use (including DDT) (Cui et al. 2020). Nevertheless, despite the incentives introduced in many countries to reduce pesticide use and the transition to organic farming (e.g. Denmark, France, Germany, Spain, the Netherlands, the United Kingdom), there is no spectacular reduction in their use (Jørgensen et al. 2019; Chèze et al. 2020). The analyses performed by Hedlund et al. (2020) show the links between economic development and pesticide consumption over time, without reducing their use at higher levels of economic development. There is also a problem with pesticides in processed foods, including detection and elimination methods (Azam et al. 2020; Albaseer 2019; Wang et al. 2019; Fortunati et al. 2019; Czaja et al. 2020).

"Pesticide toxicity risk" is one of the most important indicators of the European Union's (EU) agricultural policy, which is crucial for achieving the Sustainable Development Goals (SDGs) (Scown and Nicholas 2020). Due to threats to human health and the environment, agro-ecological approaches and new pest control strategies based on biological methods should be developed (Harrison et al. 2019; Southon et al. 2019; Yan et al. 2020; Lopes et al. 2016). It is also important to integrate mechanical care treatments with chemicals (herbicides, insecticides, etc.) (Zarzecka et al. 2020). Water pollution by pesticides used in agriculture is currently a major concern in Europe (Silva et al. 2019; Herrero-Hernández et al. 2020). Support is needed in the form of systems supporting farmers' decisions. The flow of knowledge by passing on the results of interdisciplinary research in the field of natural and social sciences is significant. These studies may be aimed at assessing risk, economic efficiency, etc. (Vasileiadis et al. 2013; Lavik et al. 2000b).

Integrated pest management (IPM) is the point of reference for the analyses of pesticide consumption carried out in this study. The basis of this concept is a holistic approach to pest and plant disease control using all available methods, while minimizing the use of chemical pesticides (Barzman et al. 2015). In this way, the pressure on the natural environment is reduced, and the biodiversity of the agricultural environment is protected. As Kogan (1998) points out, the history of IPM goes back to the end of the nineteenth century, when ecology was recognized as the basis of scientific plant protection. Over the last several decades, there has been a methodological and organizational progress in the studied subject matter, which is developing methodologies including monitoring the occurrence of harmful organisms, determining the thresholds of their economic harmfulness, organizing training courses, thematic conferences and developing consultancy and decision support systems in plant protection (Ma and Abdulai 2019; Mondino and González-Andújar 2019; Dara 2019). IPM is an extremely important element in the pursuit of sustainable agriculture, based on deep knowledge of the agricultural environment, which is to ensure the production of high-quality food without degrading the agricultural environment. IPM is globally endorsed as the future paradigm for crop protection (Stenberg 2017). Contemporary challenges in the field of IPM are also important. The literature on the subject emphasizes the need to formulate general principles of synergistic combination of traditional and innovative measures in the field of IPM, including public and private policy instruments in the field of reducing pesticide use (Lamichhane et al. 2016; Stenberg 2017; Lee et al. 2019). Interesting challenges in the area of research are the motivations and actions of farmers. Moss (2019) points to, inter alia, identifying the reasons why farmers are reluctant to use non-chemical alternatives.

The spatial scope of analyses in this paper concerns Poland. Farmers in Poland make independent decisions regarding agrotechnical operations (type of technology and technique), and their behaviour in this respect must take into consideration the principles of environmental protection. The regulations in this area include the code of good agricultural practice (GAP), and compliance with the rules contained therein helps to apply plant protection products safely and effectively. Since January 1, 2014, farmers in Poland have been obliged to comply with 
the IPM principle, which imposed new rules on them. This is defined by numerous legal acts, in particular Directive 2009/128/EC of the European Parliament and of the Council (DUUE 2009) establishing a framework for community action on the sustainable use of pesticides (Lefebvre et al. 2015; Stenberg 2017). The rule is to use all available methods and techniques, especially non-chemical ones (Karlsson Green et al. 2020). The legal obligation to apply the general principles of IPM in Poland refers to all professional users of plant protection products.

Environmental degradation caused by the use of chemical plant protection products in cultivation contributes to the search not only for alternative methods, techniques and plant protection products, but also for changes in social and economic regulations. Currently, in Polish agriculture, there is a transition phase between conventional and sustainable agriculture (Niewiadomska et al. 2020). In this context, the behaviour of agricultural producers regarding the use of chemical means of agricultural production is extremely interesting (Damalas and Koutroubas 2018). According to many authors, research in this area is neglected. In recent years, research in the subject literature has relatively rarely undertaken behavioural studies in the context described in this paper among European farmers. Chèze et al. (2020) have used the method of discrete choice experiment that includes the risk of large production losses due to pests. The authors analysed farmers' readiness to reduce the use of pesticides in France. These studies took into account, among others the following factors, the administrative framework of the practice change, the resulting reduction of the impact of pesticides on health and the environment and the risk of large production losses. The authors of these studies conclude that more research is needed to understand the drivers behind the adoption of pesticide reduction practices, especially local research. In turn, Lavik et al. (2020a) have analysed pest management strategies among Norwegian farmers (have used the method of multi-attribute decision analysis). These analyses show that the adoption of the IPM strategy can be accelerated through the granting of subsidies to farmers and the development of advisory services. A lot of research in the field of knowledge, attitudes and practices concerns African and Asian countries (Mekonnen and Agonafir 2002; Jallow et al. 2017; Mengistie et al. 2017).

The presented research is to fill the existing gap in the area of sustainable use of pesticides in Central and Eastern Europe. The use of pesticides in this area is a significant threat in terms of water and soil pollution (Székács et al. 2015; Hvězdová et al. 2018; Vašíčková et al. 2019). The aim of the study was to characterize the attitudes and practices of Polish farmers in the field of performing chemical plant protection treatments. A particular attention was paid to identifying the relationship between trends of changes in the volume of chemical plant protection products consumption and the farm area, its economic size and location (place). The main time range of the analyses covered the period of 2013-2017. In a broader context, the research aimed to assess the attitudes and practices of farmers in Poland in the field of sustainable agriculture and sustainability of modern agri-food markets and their development (Borsellino et al. 2020).

\section{Materials and methods}

Achievement of the purpose of the work was related to collecting secondary and primary data. Statistical data on total pesticide consumption in Polish agriculture and in selected crops was collected and analysed. Due to the lack of information from secondary sources regarding the behaviour of farmers, which would allow the full achievement of the objectives of the work, a representative primary (survey) research was carried out among agricultural producers in November 2017-March 2018. Surveys were conducted in 18 districts in Poland. The selection of districts was random, layered. The first layer of the draw was constituted by provinces (one province was drawn from each of the six macroregions in Poland). Then, three districts were drawn in each previously drawn province, which allowed field studies to be carried out in a diverse spatial, social and economic environment (Fig. 1).

In total, surveys were carried out in 1101 farms in Poland. Participation in the research was on a voluntary basis. The characteristics of respondents are presented in Table 1.

The basic research tool was a survey questionnaire. The implementation of such extensive research took place in cooperation with agricultural advisory centres operating in the studied area. The data was collected through direct interviews conducted by an interviewer (agricultural advisor). In the survey, respondents indicated the direction of changes in the amount of consumed pesticides and described agricultural practices that are characteristic in the use of pesticides on their farm. The questions in the survey concerned the activities of agricultural producers in the period of 2013-2017. These practices are directly related to plant protection treatments and are listed in the label instruction. The respondents answered four questions (three variants of answers were possible: "yes," "no," "I don't know"):

- I choose plant protection products in such a way as to minimize the negative impact of plant protection treatments on non-target organisms;

- I limit the number of treatments and the amount of used plant protection products to the necessary minimum;

- I counteract the emergence of resistance of harmful organisms to plant protection products through proper selection and alternate use of these products;

- I am familiar with the methodology of integrated plant management for individual crops on my farm. 


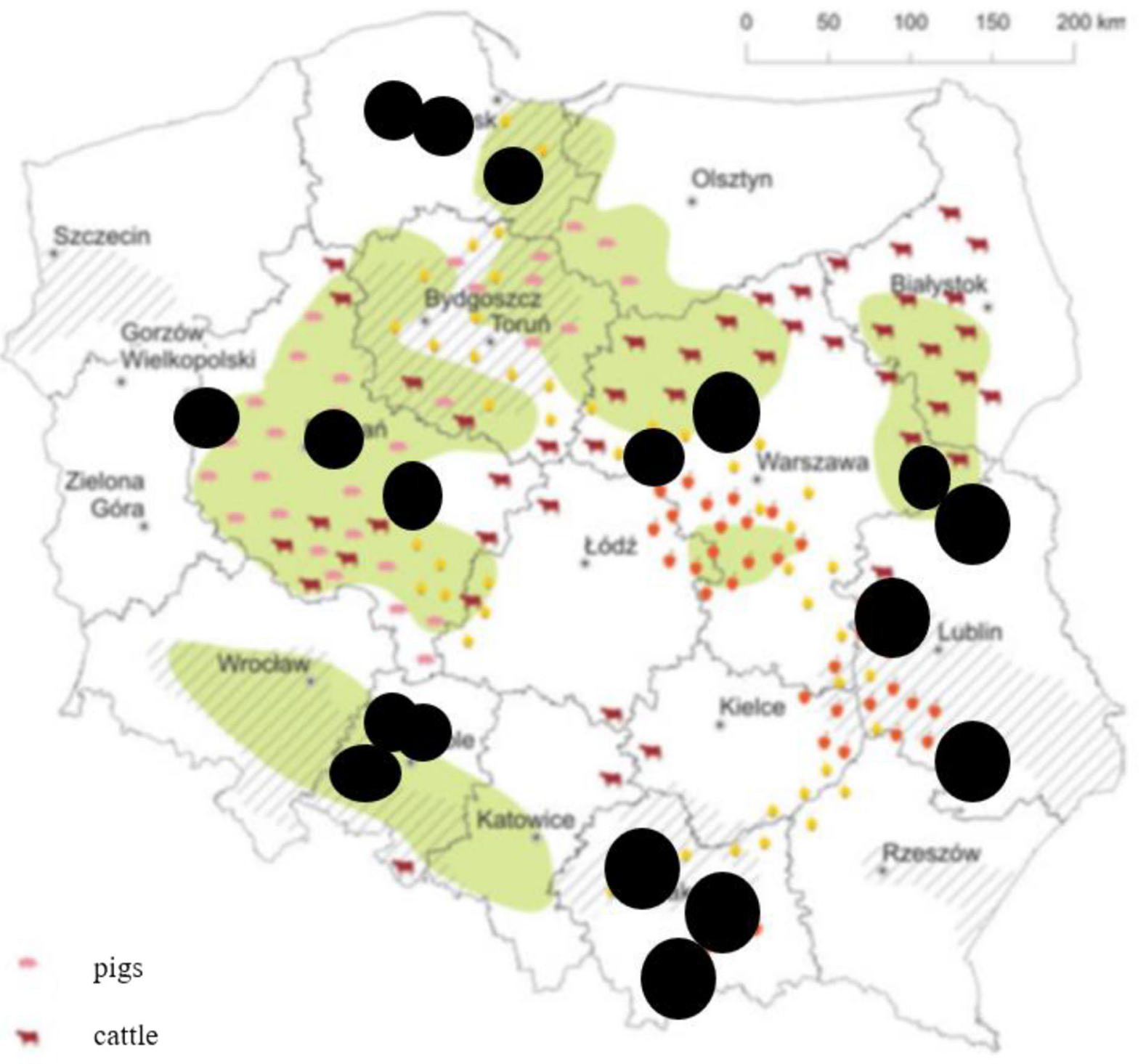

* areas of intensive fruits and vegetable production

areas of competitive agriculture

spatial extent of field studies

\section{areas of high environmental potential}

Fig. 1. Main food producing areas in Poland and spatial extent of field studies. Source: Own elaboration based on https://www.igipz.pan.pl/tl_files/igipz/ ZGWiRL/ARP/01.Znaczenie\%20rolnictwa\%20w\%20gospodarce\%20Polski.pdf (accessed 13.07.2020)

Due to the fact that the research intention was to learn the coexistence of the direction of changes in the area of pesticide use with selected features of a farm, a multiple correspondence analysis was used. This method was successfully used in the same subject matter (assessment of environmental risk and the effectiveness of agrotechnical operations, farmers' behaviour regarding the use of plant protection products, fertilizers, etc.) (Dmowska and Ilieva 1995; Piwowar 2020; Svobodová et al. 2020). The input data was compiled in the form of a Burt table (symmetrical block matrix). Then the percentage distributions in rows and columns, total distributions, expected numbers, differences between observed and expected numbers, standardized deviations and share in the total value of chi-square statistics were determined. The analysis of correspondence made in the paper was carried out using the computer program STATISTICA 13.3. Research methods of descriptive statistics and analysis were also used, with particular reference to comparative and literature analysis 
Table 1 Basic general characteristics of interviewed farmers

\begin{tabular}{lll}
\hline Specification & $\begin{array}{l}\text { Population } \\
\text { (pcs) }\end{array}$ & $\begin{array}{l}\text { Share in the test sample } \\
(\%)\end{array}$ \\
\hline
\end{tabular}

Age of respondents

\begin{tabular}{lllllll}
$18-29$ y & 128 & 11.6 & $€>200,000$ & 4 & 0.4 \\
$30-39$ y & 250 & 22.7 & No data & 66 & 6.0 \\
$40-49$ y & 328 & 29.8 & Total & 1101 & 100 \\
\cline { 2 - 7 }
\end{tabular}

$50-59$ y $281 \quad 25.5$

$\begin{array}{lll}>60 \mathrm{y} & 102 & 9.3\end{array}$

No data $\quad 12 \quad 1.1$

Total $1101 \quad 100$

Gender of respondents

$\begin{array}{lll}\text { Women } & 197 & 17.9 \\ \text { Men } & 901 & 81.8 \\ \text { No data } & 3 & 0.3 \\ \text { Total } & 1101 & 100 \\ \text { Education level of respondents } & & \\ \text { Primary } & 44 & 4.0 \\ \text { Graduate vocational school } & 389 & 35.3 \\ \text { Secondary } & 518 & 47.0 \\ \text { Higher } & 142 & 12.9 \\ \text { No data } & 8 & 0.7 \\ \text { Total } & 1101 & 100\end{array}$

Number of years worked in agricultural holding

$\begin{array}{lll}1-5 \mathrm{y} & 90 & 8.2 \\ 6-10 \mathrm{y} & 146 & 13.3 \\ 11-15 \mathrm{y} & 119 & 10.8 \\ 16-20 \mathrm{y} & 172 & 15.6 \\ 21-25 \mathrm{y} & 138 & 12.5 \\ 26-30 \mathrm{y} & 152 & 13.8 \\ >31 \mathrm{y} & 282 & 25.6 \\ \text { No data } & 2 & 0.2 \\ \text { Total } & 1101 & 100\end{array}$

Selected features of agricultural holdings

Area of agricultural lands (ha)

$\begin{array}{lll}<5 & 88 & 8.0 \\ 5-9.99 & 195 & 17.7 \\ 10-14.99 & 191 & 17.3 \\ 15-19.99 & 136 & 12.4 \\ 20-29.99 & 164 & 14.9 \\ 30-49.99 & 170 & 15.4 \\ 50-99.99 & 115 & 10.4 \\ >100 & 41 & 3.7 \\ \text { No data } & 1 & 0.1 \\ \text { Total } & 1101 & 100 \\ \text { Economic size of agricultural holding (SO) } & \\ €<10,000 & 316 & 28.7 \\ € 10,100-13,000 & 156 & 14.2 \\ € 13,100-20,000 & 188 & 17.1 \\ € 20,100-50,000 & 232 & 21.1 \\ € 50,100-100,000 & 99 & 9.0\end{array}$

Table 1 (continued)

\begin{tabular}{lll}
\hline Specification & $\begin{array}{l}\text { Population } \\
(\text { pcs })\end{array}$ & $\begin{array}{l}\text { Share in the test sample } \\
(\%)\end{array}$ \\
\hline$€ 100,100-200,000$ & 40 & 3.6 \\
$€>200,000$ & 4 & 0.4 \\
No data & 66 & 6.0 \\
Total & 1101 & 100 \\
\hline
\end{tabular}

Source: Own study based on questionnaire surveys $(N=1101)$

and descriptive methods. The analyses carried out in this work are a section of the research area related to low-carbon agriculture development in Poland. The work related to this research project was financed by the National Science Centre in Poland.

\section{The use of pesticides in Polish agriculture-volume and structure of consumption}

Poland is a leading food producer in the European Union (Firlej et al. 2017; Bojnec and Fertő 2019). Taking into consideration agricultural production, Poland is at the forefront in the production of poultry meat, and in the field of plant production - wheat, rapeseed, sugar beet, triticale and rye. Poland is also distinguished by a high volume of berry fruit production (mainly strawberries, raspberries and currants), as well as being one of the largest producers of onions, cabbage and cauliflowers (Fig. 2).

Agricultural production in Poland in 2018 covered an area of 18.608 million ha. Due to the share of agricultural area in the total area, Poland is in third place in Europe (behind France and Spain). A characteristic feature of Polish agriculture is the large diversity and fragmentation of farms in terms of area. The average usable agricultural area (UAA) per farm in 2018 in Poland was 11.3 ha. The average farm size has been increasing in recent years (in 2002, it was 5.8 ha; in 2011, 9.1 ha) (Rolnictwo 2019). Despite the increase in the average area of a farm, still more than half of farms in Poland (51.9\%) operate on no more than 5 ha of UAA. However, these farms have only $12.8 \%$ of total utilized agricultural areas in Poland (Rolnictwo 2019).

In the European Union countries, there are clear differences in the volume of pesticide sales, which depends on the natural conditions of agricultural production in a particular area. Taking into consideration the individual groups of plant protection products, compared with the countries of Western and Southern Europe, relatively large amounts of herbicides are used in Poland (over 50\% of sales structure) (Table 2).

Currently, it should be stated that the level of pesticide consumption is actually relatively low in relation to other European Union countries (Fig. 3). 
Fig. 2. Market share and position of Poland in the classification in terms of the production volume of selected agricultural products in the European Union in 2018.

Source: Statistical Yearbook of Agriculture, Statistics Poland, Warsaw 2020

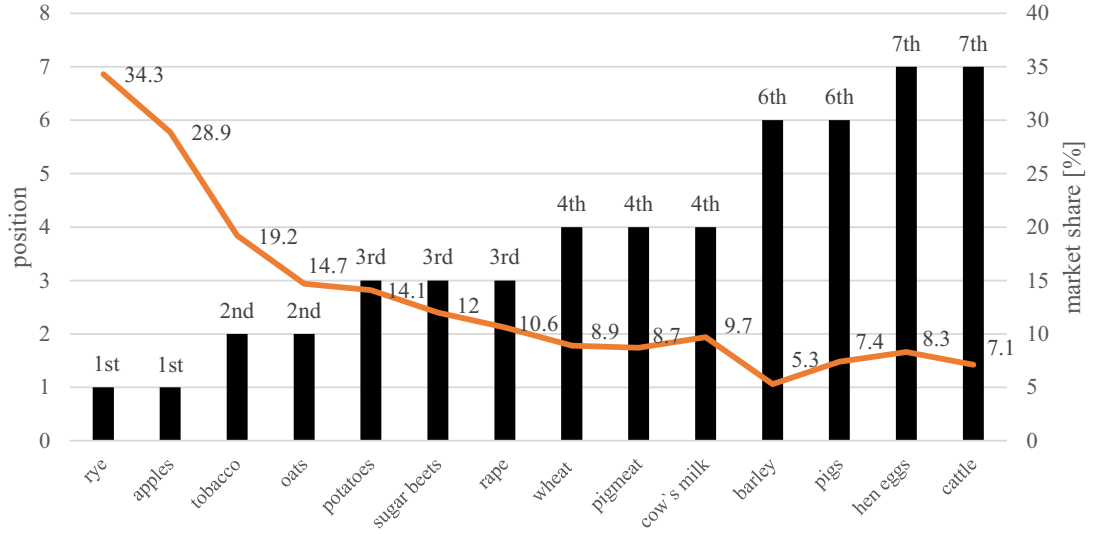

According to http://www.fao.org/faostat/en/\#data/EP/ visualize (accessed 14.10.2020) data, the average pesticide consumption in Poland in 2014-2018 was $2.12 \mathrm{~kg} / \mathrm{ha}$. Higher consumption was recorded in each of the Western
Table 2 Sales of pesticides in EU in 2018

\begin{tabular}{|c|c|c|c|c|c|c|}
\hline Specification & $\begin{array}{l}\text { Fungicides } \\
\text { and } \\
\text { bacteriocides } \\
\text { (tonnes) }\end{array}$ & $\begin{array}{l}\text { Herbicides, } \\
\text { haulm } \\
\text { destructors and } \\
\text { moss killers }\end{array}$ & $\begin{array}{l}\text { Insecticides } \\
\text { and } \\
\text { acaricides }\end{array}$ & Molluscicides & $\begin{array}{l}\text { Plant } \\
\text { growth } \\
\text { regulators }\end{array}$ & $\begin{array}{l}\text { Other } \\
\text { plant } \\
\text { protection } \\
\text { products }\end{array}$ \\
\hline Belgium & 2458 & 2648 & 476 & 16 & 269 & 769 \\
\hline Bulgaria & 1798 & 2607 & 593 & (c) & 18 & 25 \\
\hline Czechia & 1755 & 2572 & 292 & 8 & 265 & 287 \\
\hline Denmark & 484 & 1905 & 44 & 15 & 202 & 1 \\
\hline Germany & 11,682 & 14,533 & 16,237 & 154 & 2138 & 181 \\
\hline Estonia & 107 & 428 & 29 & (c) & 73 & (c) \\
\hline Ireland & 602 & 1833 & 29 & 10 & 161 & 17 \\
\hline Greece & 1729 & 1833 & 1009 & 2 & 119 & 169 \\
\hline Spain & 38,067 & 16,593 & 6488 & (c) & 195 & (c) \\
\hline France & 39,087 & 34,392 & 5728 & 385 & 3567 & 1811 \\
\hline Croatia & 767 & 718 & 127 & 2 & 80 & 4 \\
\hline Italy & 31,539 & 6880 & 1653 & 36 & 475 & 13,455 \\
\hline Cyprus & 823 & 161 & 151 & 2 & 0 & 47 \\
\hline Latvia & 213 & 965 & 36 & 5 & 355 & 13 \\
\hline Lithuania & 677 & 1054 & 57 & (c) & 262 & (c) \\
\hline Luxembourg & (c) & 54 & (c) & 0 & 8 & (c) \\
\hline Hungary & 3535 & 3824 & 787 & 1 & 169 & 219 \\
\hline Malta & 83 & 3 & 3 & 1 & 0 & (c) \\
\hline Netherlands & 4288 & 2978 & 243 & 11 & 386 & 1476 \\
\hline Austria & 2269 & 1277 & 1569 & 6 & 84 & 75 \\
\hline Poland & 7992 & 11,371 & 1770 & (c) & 1609 & 415 \\
\hline Portugal & 4335 & 1939 & 675 & 11 & 3 & 1095 \\
\hline Romania & 4542 & 5188 & 1012 & 5 & 313 & 48 \\
\hline Slovenia & 849 & 257 & 55 & 2 & 5 & 4 \\
\hline Slovakia & 676 & 1329 & 151 & 1 & 268 & 65 \\
\hline Finland & 3814 & 982 & 21 & 1 & 68 & 14 \\
\hline Sweden & 223 & 1483 & 94 & (c) & 50 & 22 \\
\hline
\end{tabular}

Source: https://ec.europa.eu/eurostat/statistics-explained/images/b/be/Table_1_Sales_of_pesticides\%2C_by_ country\%2C_2011_and_2018_\%28tonnes\%29.png (accessed 24.09.2020)

(c) confidential value 
Fig. 3. Average use of pesticides per area of cropland from 2014 to 2018 in European countries. Source: Authors' own elaboration based on http://www.fao.org/ faostat/en/\#data/EP/visualize (accessed 14.10.2020)

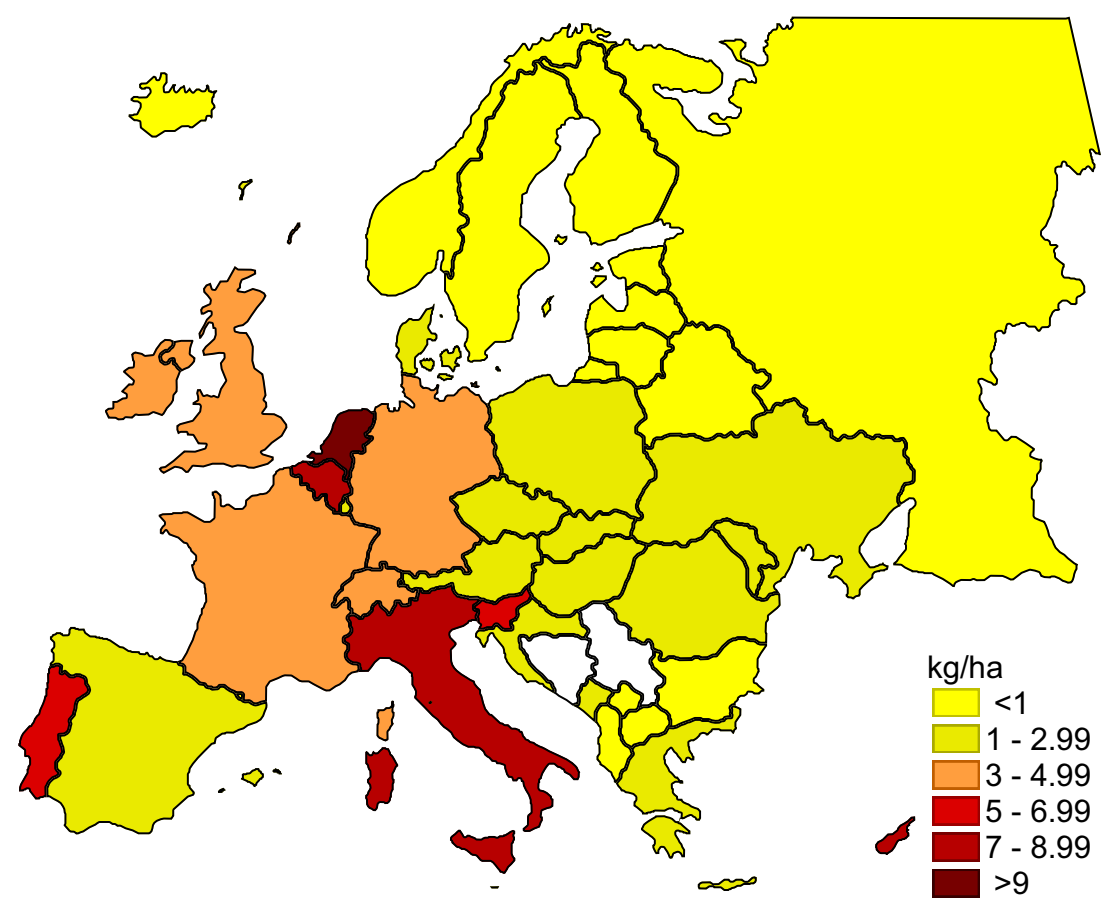

European countries, including Germany (3.9 kg/ha), France $(3.83 \mathrm{~kg} / \mathrm{ha})$ and Spain $(3.57 \mathrm{~kg} / \mathrm{ha})$. An important issue in the studied problems is, to a large extent, the lack of information regarding the volume of pesticide use in spatial terms. Previous practices in official statistics in this area do not meet the analytical needs of researchers of this phenomenon for the needs of practice, science and politics. Data on the overall volume of sales of plant protection products in Poland are presented in Fig. 4. In order to present a broader context in the area of pesticide sales, the time range of analyses was extended by the years 2005, 2010 and 2013-2018.

The volume of sales of plant protection products in Poland in 2005-2018 increased by 24,200 tonnes (by mass) and in

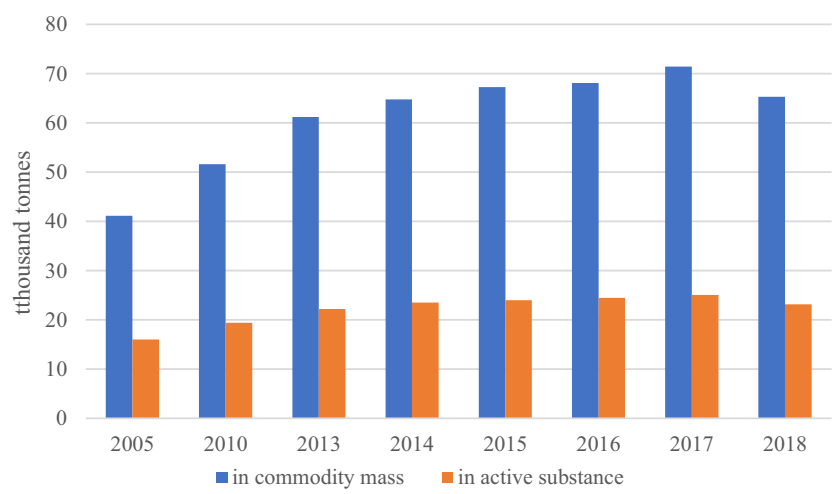

Fig. 4. Sales of plant protection products in Poland. Deliveries on the domestic market by producers and importers; from 2018 by holders of the authorization of the Minister of Agriculture and Rural Development for the marketing of plant protection products. Source: Authors' own elaboration based on Means of production in agriculture in the 2018/19 farming year. Statistics Poland, Warsaw 2020
2018 amounted to 65,335 tonnes. In terms of tonnage, expressed in the amount of active substance, the increase in pesticide sales in Poland in 2005-2018 amounted to 7139 tonnes. It is worth noting that the volume of sales of plant protection products in Poland was increasing steadily until 2017. A decrease in dynamics and a reversal of trends were recorded in 2018. In 2018, the volume of sales of pesticides in Poland expressed in the amount of active substance $(23,178$ tonnes) was slightly lower than in 2014 (23,557 tonnes).

Considering the generic structure, herbicides are consumed the most in Poland. In 2018, sales of this product group (in terms of active substance) amounted to $11,370.7$ tonnes (Table 2). The group of "Herbicides, haulm destructors and moss killers" constituted half of the pesticides sold on the Polish market. In the sales structure of pesticides, in addition to herbicides, in terms of quantity, an important group of plant protection products were fungicidal and bactericidal preparations $(34.5 \%)$.

Data from official statistics in Poland (Rynek 2019) regarding the scope of applied chemical protection relate to the consumption of chemical agents in the cultivation of a few crop species (Table 3).

Both presented data in Table 3 as well as the literature (Łozowska et al. 2013; Jankowska et al. 2019; Szpyrka et al. 2016) on the subject prove that high consumption of pesticides is particularly noted in horticultural production (e.g. apples and pears). In Poland, due to the high share of cereals in arable land and the significant importance of gardening, herbicides and fungicides are used most. Insecticides and acaricides are much less used. 
Table 3 Consumption of plant protection products in the studied crops in Poland in 2014-2018 (in $\mathrm{kg}$ of active substance/ha of crop)

\begin{tabular}{|c|c|c|c|c|c|}
\hline Specification & $\begin{array}{l}\text { Fungicides and } \\
\text { bactericides }\end{array}$ & $\begin{array}{l}\text { Herbicides, haulm } \\
\text { destructors and moss } \\
\text { killers }\end{array}$ & $\begin{array}{l}\text { Insecticides } \\
\text { and acaricides }\end{array}$ & $\begin{array}{l}\text { Other plant } \\
\text { protection } \\
\text { products }\end{array}$ & Total \\
\hline \multicolumn{6}{|l|}{2014} \\
\hline Fodder beet & 0.06 & 0.81 & 0.01 & 0.00 & 0.88 \\
\hline Spring wheat & 0.21 & 0.38 & 0.00 & 0.09 & 0.68 \\
\hline Oat & 0.01 & 0.52 & 0.00 & 0.01 & 0.54 \\
\hline Currant & 1.02 & 0.59 & 0.10 & 0.00 & 1.71 \\
\hline Plum & 1.68 & 0.37 & 0.32 & 0.00 & 2.37 \\
\hline \multicolumn{6}{|l|}{2015} \\
\hline $\begin{array}{l}\text { Cereal } \\
\text { mixtures }\end{array}$ & 0.01 & 0.55 & 0.00 & 0.00 & 0.56 \\
\hline Winter barley & 0.45 & 0.60 & 0.01 & 0.01 & 1.12 \\
\hline Cherries & 2.07 & 0.01 & 0.06 & 0.00 & 2.14 \\
\hline \multicolumn{6}{|l|}{2016} \\
\hline Winter tricale & 0.24 & 0.44 & 0.01 & 0.08 & 0.76 \\
\hline Corn & 0.02 & 0.71 & 0.01 & 0.01 & 0.75 \\
\hline Sugar beet & 0.25 & 2.35 & 0.04 & 0.03 & 2.67 \\
\hline Onion & 2.46 & 1.78 & 0.02 & 0.30 & 4.56 \\
\hline Carrot & 0.55 & 0.96 & 0.15 & 0.00 & 1.66 \\
\hline Pear & 5.61 & 0.13 & 0.34 & 0.00 & 6.08 \\
\hline \multicolumn{6}{|l|}{2017} \\
\hline Cucumbers & 3.80 & 0.04 & 0.01 & 0.00 & 3.85 \\
\hline $\begin{array}{l}\text { Cucumber } \\
\text { under } \\
\text { shelter }\end{array}$ & 2.93 & 0.00 & 0.04 & 0.00 & 2.98 \\
\hline $\begin{array}{l}\text { Ground } \\
\text { tomatoes }\end{array}$ & 6.69 & 0.36 & 0.00 & 0.19 & 7.24 \\
\hline $\begin{array}{l}\text { Tomatoes } \\
\text { under } \\
\text { shelter }\end{array}$ & 2.53 & 0.00 & 0.06 & 0.00 & 2.60 \\
\hline Winter wheat & 0.55 & 0.41 & 0.05 & 0.31 & 1.32 \\
\hline Strawberries & 1.95 & 0.73 & 0.04 & 0.03 & 2.74 \\
\hline Potatoes & 2.79 & 0.64 & 0.04 & 0.01 & 3.49 \\
\hline Rye & 0.08 & 0.17 & 0.00 & 0.06 & 0.31 \\
\hline \multicolumn{6}{|l|}{2018} \\
\hline Apple & 9.90 & 0.30 & 0.25 & 0.01 & 10.46 \\
\hline Spring barley & 0.11 & 0.48 & 0.01 & 0.02 & 0.62 \\
\hline Raspberries & 1.08 & 0.21 & 0.04 & 0.00 & 1.33 \\
\hline Winter rape & 0.45 & 0.92 & 0.29 & 0.08 & 1.74 \\
\hline Sour cherry & 5.28 & 0.28 & 0.05 & 0.00 & 5.60 \\
\hline
\end{tabular}

Source: Authors' own elaboration based on Rynek środków produkcji dla rolnictwa. Analizy Rynkowe 2019, nr 46, p. 25 [In Polish]

\section{Pesticide use practices in Poland-results of empirical research}

As mentioned in the introduction, IPM has been in force in Poland since January 1, 2014. Its main assumption is the priority of using non-chemical methods of plant protection. One of the basic principles of plant protection at the farm level is the rational use of plant protection products. In order to make it happen, it is necessary to be familiar with the current methodologies of integrated plant protection, plant protection programs and indications for signalling harmful organisms and implement decision support systems in plant protection (Swiergiel et al. 2019; Szelag-Sikora et al. 2019). In relation to the thematic scope of the paper, i.e. indicating practices in the field of chemical plant protection, below are the respondents' answers to four key issues. 
According to the research, more than half of the respondents declared knowledge of integrated plant protection methodology, counteracted the emergence of resistance of harmful organisms, limited the number of treatments and selected appropriate pesticides (Fig. 5).

The analyses show that the majority of respondents $(82.4 \%)$ declared to minimize the number of treatments and the amount of plant protection products. However, the declared knowledge of the integrated protection methodology is worrying. This is due to the fact that $35.5 \%$ of the respondents declared they did not know the methodology of IPM for individual crops on their farm. This raises questions about the effectiveness of training activities, including mandatory training for people who perform plant protection treatments in agriculture. The certificate of completion of such training is valid for a period of 5 years from the date of completion of the training and entitles to perform treatments using plant protection products.

Inspired by the results obtained concerning the change in the amount of pesticide consumption declared by farmers, a study was carried out on the relationship between the direction of change and the characteristics (attributes) of a farm. Four variables were selected for detailed analyses: (1) direction of changes in the amount of pesticide use, (2) area of arable land, (3) economic size of a farm and (4) district. In order to determine the existence of dependence and its strength, values of $\chi^{2}$ statistics and mean square multivariate were calculated (Table 4).

The critical values read from the chi-square distribution tables, at a given level of significance, for all pairs of features $\left(\chi_{\alpha}^{2}=20.0902\right.$ or 23.2093), are smaller than the calculated $\chi^{2}$ statistics (93.8249, arable land area; 117.9304, economic size; 49.5906, district). This means that the hypothesis about the independence of the examined features should be rejected, thus stating that the direction of changes in the amount of pesticide consumption depends on the area of the farm and its economic size and the district in which the farm is located.

Figure 6 presents in three-dimensional space the result of an analysis of correspondence of the declared direction of changes in pesticide consumption (from the period of 20132017) with the features of farms. The use of correspondence analysis allowed presenting graphically the relationships among the studied variables.

Correspondence analysis showed that there is a coexistence between variable E3 (decrease in pesticide consumption) and variables U1 (farms below 5 ha of UAA) and S1 (economic size below $€ 10,000)$. Moreover, agricultural producers, who declared an increase in pesticide consumption (E1), ran relatively larger farms, which are economically stronger (U4, S5). The correlation between declarations of increase in pesticide use and districts in which intensive agricultural production is carried out was also characteristic (P4, P5). The location of point $\mathrm{E} 2$ (no change in the amount of pesticide consumption) indicates average profiles in terms of the studied variables. This arrangement of points indicates that there is a slight differentiation between these categories.

The problem of linking farm characteristics with the direction of changes in agrochemicals consumption is an interesting research area. According to the author, a feature of modern plant protection economics should be the development of new levels of analyses in the field of organization and economics of farms (e.g. in terms of strategic and organizational as well as behavioural approach). The empirical conducted research shows the necessity of changes in the policy area and real practices in the examined area (Piwowar 2018a). The purpose of the review of active substances of plant protection products carried out in the European Union for several years is to ensure the safety of consumers and the natural environment (Boucaud-Maitre et al. 2019). A lot of new preparations are being introduced to the market with increasingly high-quality
Fig. 5. Respondents' declarations regarding practical aspects of performing plant protection treatments. Source: Own study based on questionnaire surveys $(N$ $=1101)$

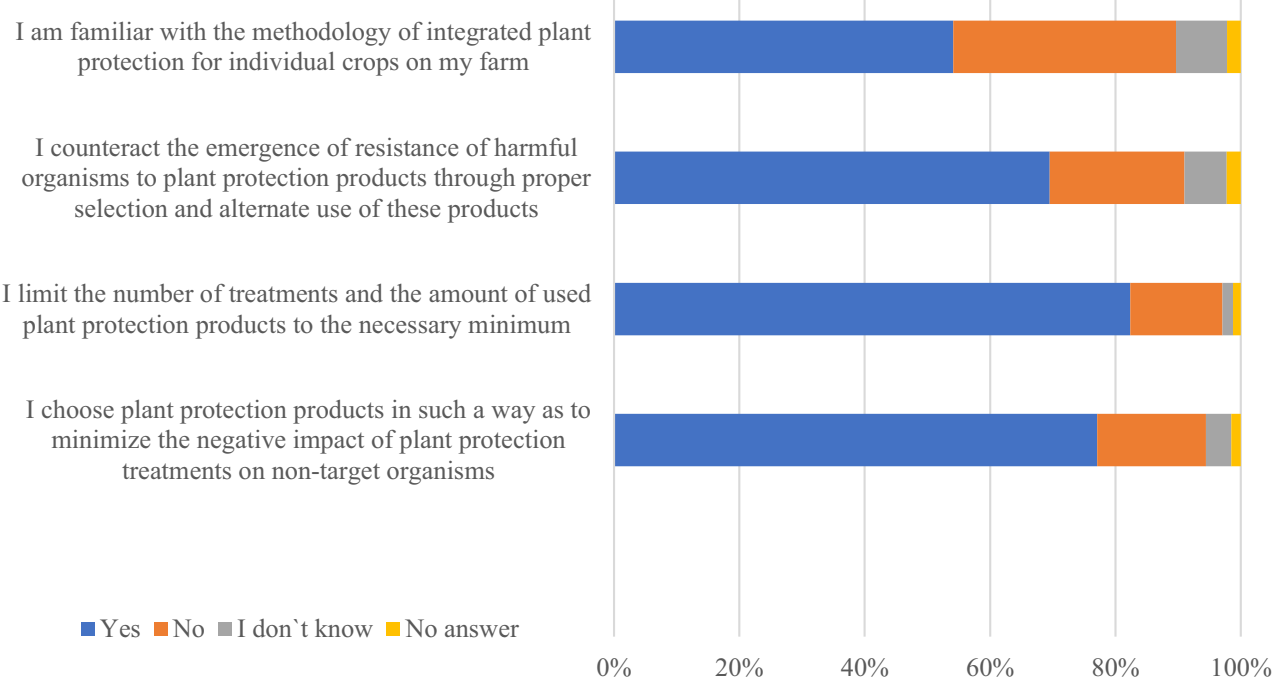


Table 4 Statistics values $\chi^{2}$, critical values $\chi_{\alpha=0.01}^{2}$ (in parentheses) and mean square contingency $\varphi^{2}$ (italics) for the following features: pesticide use, arable land area, economics size of agriculture holding, and district

\begin{tabular}{llll}
\hline Specification & Arable land area $c=5^{* *}$ & $\begin{array}{l}\text { Economic size of agricultural } \\
\text { holding } c=6^{* *}\end{array}$ & District $c=6^{* *}$ \\
\hline $\begin{array}{c}\text { Pesticide use } \\
r=3^{* *}\end{array}$ & $93.8249(20.0902) 0.0907$ & $117.9304(23.2093) 0.1141$ & 49.5906 (23.2093) 0.0480 \\
\hline
\end{tabular}

Source: Own study based on questionnaire surveys $(N=1101)$

* Critical values $\chi_{\alpha}^{2}=0.01$ read from the tables for $(r-1) \times(c-1)$ degrees of freedom

$* *$ Number of rows and columns of the variables analysed requirements (toxicological and ecotoxicology). A lot of substances were withdrawn from use, which largely limited the choice of agricultural producers. In the case of small farms, the effectiveness of protection using agrotechnical and biological methods can be relatively high. In the case of large farms, the need for stronger motivation to change behaviour in the area of reducing pesticide use is evident. In addition to formal changes, including economic and fiscal stimuli, institutional changes are necessary. It is important to support the creation and development of agricultural institutions and to build social capital. It is necessary to develop professional consultancy in the field of plant protection. Greater awareness among farmers in the field of environmental protection and the need to take into consideration issues regarding pesticide resistance should accelerate the development of the biopesticide market. It is justified, due to the occurrence of negative externalities, to develop a modification of the system that internalizes external costs in the studied issues.

The results of analyses can be used by scientists and decision-makers to assess the existing solutions in the field of pesticide management practices and their contribution to the sustainable development of agriculture. The presented research results can be the basis for comparisons on local, regional and wider spatial scales. Further research directions should also enable interdependence with other factors. Additional variables may take into consideration, inter alia, the state of the environment, the number of incidents related to poisoning people with pesticides and the number of incidents related to bee poisoning. Further studies in this field should also consider other inputs, such as fertilizers. Just like irrational use of pesticides, irrational use of fertilizers can lead to threats to the natural environment. In the case of fertilizers, this applies especially to two components - nitrogen and phosphorus. These nutrients are key in the eutrophication process (Dodds and Smith 2016; Dou et al. 2019). It is worth emphasizing that the consumption of mineral fertilizers in Poland is one of the highest in Europe (Piwowar 2018b; Piwowar 2019).

An important element contributing to sustainable pesticide management is progress and new concepts in precision farming. The key element in this area is the application of an optimal, variable dose of pesticides based on application maps. Practical use of precision farming tools and techniques in the field of pesticides allows reducing environmental and health risks. A model of precision agriculture should be systematically implemented, in which the treatments of precise application of plant protection products are of particular importance. These solutions significantly improve the operator's safety and reduce the risk of contamination of the natural environment. As technical progress is rapid and the costs of advanced electronic systems in the field of precision farming decrease, these techniques can be implemented not only in large-scale farms. Personal protective equipment also plays a very important role in the area of broadly understood safety and striving for sustainable development in the field of pesticide management (Garrigou et al. 2020). Further research is needed not only in the area of modern technical means for pesticide application and effective personal protective equipment, but also in methods and techniques of pesticide monitoring in ecosystems (analyses of direct and indirect effects of pesticide use on the food chain, interactions of pesticides with other natural and anthropogenic factors, etc.).

The current policy of the European Union aims to reduce the use of pesticides. The European Commission proposes that by 2030, EU countries should reduce the amount of used pesticides by at least $50 \%$. In this way, the European Union plans to stop the problem of the mass extinction of wild pollinators and protect biodiversity. On the other hand, reducing the amount of pesticides used in crops may mean a significant drop in yield, which will consequently lower farm incomes. Therefore, comprehensive changes and an integrated approach to agricultural and environmental policies are necessary (Möhring et al. 2020a, 2020b).

\section{Summary}

In the European Union countries, integrated pest management is an obligation, and in relation to Poland, this requirement has been in force since 2014. Despite the implemented directives, there was no decrease in the use of pesticides in Poland, and moreover, until 2017, there was a systematic increase in the volume of their use. Thus, further actions are necessary to promote agriculture that is more environmentally friendly, 


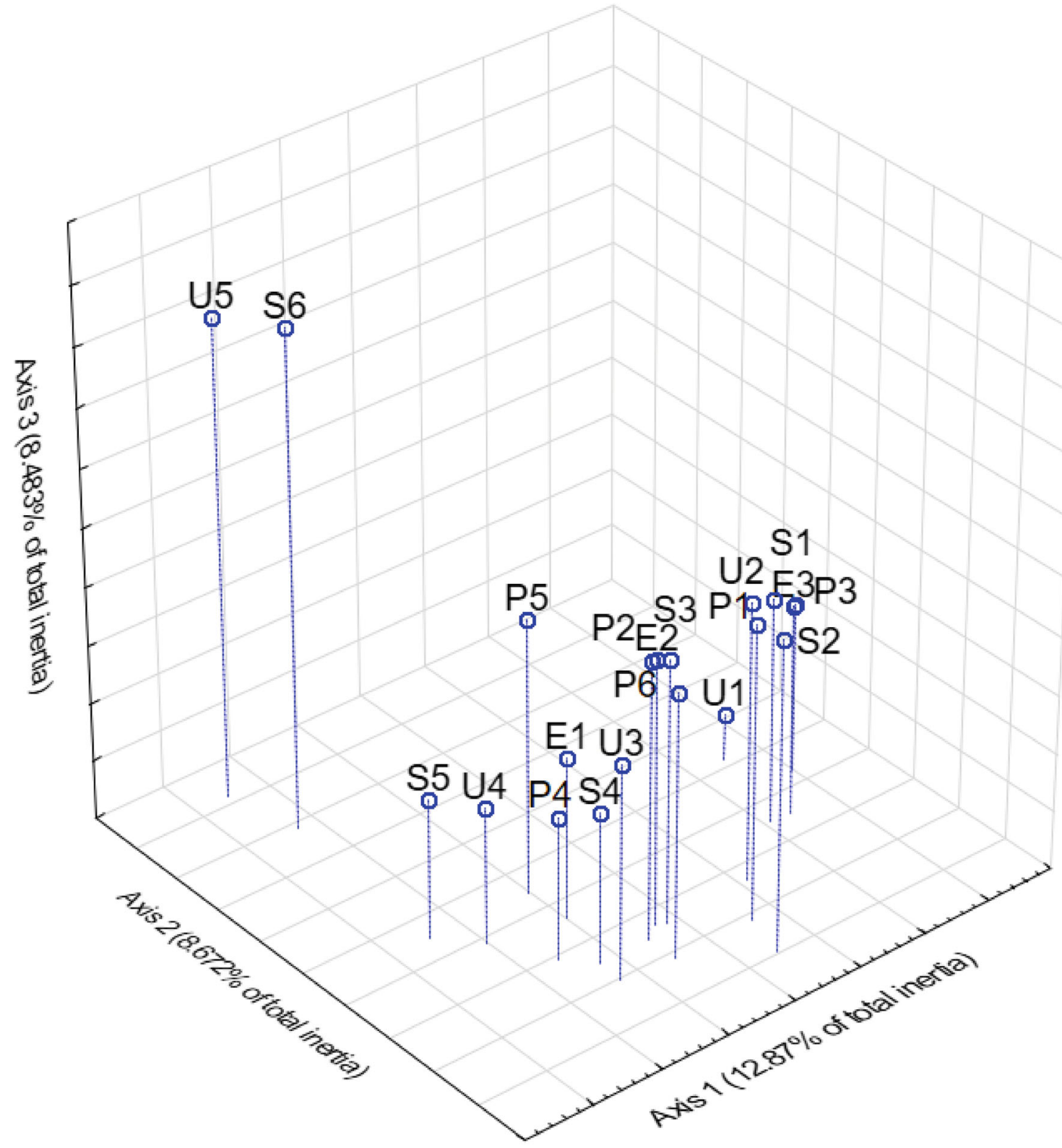

\begin{tabular}{|c|c|c|c|c|c|c|c|c|c|c|c|c|c|c|c|c|c|c|c|c|}
\hline \multirow[b]{2}{*}{ Variable } & \multicolumn{3}{|c|}{$\begin{array}{c}\text { Volume of } \\
\text { pesticides used }\end{array}$} & \multicolumn{5}{|c|}{ Arable land area (ha) } & \multicolumn{6}{|c|}{$\begin{array}{c}\text { Economic size of agricultural holding } \\
\text { (SO) }\end{array}$} & \multicolumn{6}{|c|}{ District } \\
\hline & 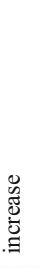 & 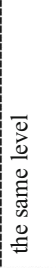 & 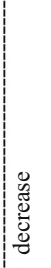 & ? & बे & बे & के & \begin{tabular}{l}
$\propto$ \\
\hdashline
\end{tabular} & 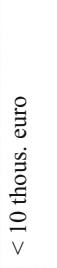 & 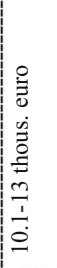 & 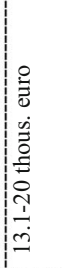 & 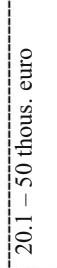 & 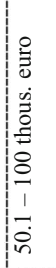 & 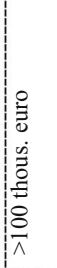 & 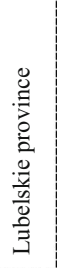 & 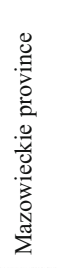 & 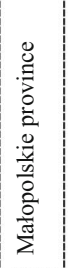 & 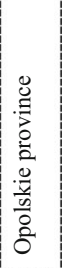 & $\begin{array}{l}0 \\
0 \\
0 \\
0 \\
0 \\
0 \\
0 \\
0 \\
0 \\
0 \\
0 \\
0 \\
0\end{array}$ & 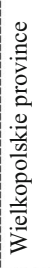 \\
\hline Symbol & E1 & E2 & E3 & U1 & $\mathrm{U} 2$ & U3 & U4 & U5 & S1 & S2 & S3 & S4 & S5 & S6 & $\mathrm{P} 1$ & $\mathrm{P} 2$ & P3 & P4 & P5 & P6 \\
\hline
\end{tabular}

Fig. 6 Graphic presentation of the results of the correspondence analysis of the direction of changes in the level of pesticides use with the analysed features of agricultural holdings. Source: Own study based on questionnaire surveys $(N=1101)$ 
including the use of non-chemical methods of plant protection. There is a need to continue control programs for pesticide residues in all agricultural products, especially those where high doses of pesticides are applied (mainly in horticulture).

The main trend of the considerations proposed in the paper is the existence of a relationship between the direction of pesticide consumption (increase, no change, decrease) and the production and economic attributes of farms. Statistical analysis showed the existence of strong relationships between the economic size of farms and the direction of changes in pesticide consumption $\left(\varphi^{2}=0.1141\right)$. Detailed results also make it possible to state the relationship between the direction of changes in pesticide consumption and the size of a farm and its location. The result from multiple correspondence analysis shows that the decrease in pesticide consumption concerned especially small farms, economically weak. These observations can provide useful tips in the real and regulatory sphere. There is insufficient motivation for farmers running large farms to reduce the use of pesticides. The legal provisions lead to both a reduction in the diversity of plant protection products used and to a small extent contribute to the reduction of pesticide use in Polish agriculture. The results of the survey showed the need to increase the knowledge and skills of farmers in the research area. A significant part of the respondents did not know the methodology of IPM, and the cultivation of which was carried out on their farms. In addition to formal changes, including economic and fiscal stimuli, institutional and behavioural changes in farmers are necessary. The growing concentration and specialization of production on farms in Poland is a factor contributing to the strengthening of the role of advisory services in this area. It is the basis for creating coherent strategies and procedures in the area of IPM at the farm level. It is necessary to support further activities in the field of protection and rational use of pesticides in Polish agriculture.

Funding This study was conducted and financed in the framework of the research project "The state and prospects of the development of lowcarbon agriculture in Poland and the behaviour of agricultural producers," granted by the National Science Centre in Poland, program SONATA, grant No. 2016/21/D/HS4/00087.

Open Access This article is licensed under a Creative Commons Attribution 4.0 International License, which permits use, sharing, adaptation, distribution and reproduction in any medium or format, as long as you give appropriate credit to the original author(s) and the source, provide a link to the Creative Commons licence, and indicate if changes were made. The images or other third party material in this article are included in the article's Creative Commons licence, unless indicated otherwise in a credit line to the material. If material is not included in the article's Creative Commons licence and your intended use is not permitted by statutory regulation or exceeds the permitted use, you will need to obtain permission directly from the copyright holder. To view a copy of this licence, visit http://creativecommons.org/licenses/by/4.0/.

\section{References}

Aktar W, Sengupta D, Chowdhury A (2009) Impact of pesticides use in agriculture: their benefits and hazards. Interdiscip Toxicol 2(1):1-12

Albaseer SS (2019) Factors controlling the fate of pyrethroids residues during post-harvest processing of raw agricultural crops: an overview. Food Chem 295:58-63. https://doi.org/10.1016/j.foodchem. 2019.05.109

Arena M, Sgolastra F (2014) A meta-analysis comparing the sensitivity of bees to pesticides. Ecotoxicology 23(3):324-334

Azam SR, Ma H, Xu B, Devi S, Siddique MAB, Stanley SL, Bhandari B, Zhu J (2020) Efficacy of ultrasound treatment in the and removal of pesticide residues from fresh vegetables: a review. Trends Food Sci Technol 97:417-432. https://doi.org/10.1016/j.tifs.2020.01.028

Bart S, Amossé J, Lowe CN, Mougin C, Péry AR, Pelosi C (2018) Aporrectodea caliginosa, a relevant earthworm species for a posteriori pesticide risk assessment: current knowledge and recommendations for culture and experimental design. Environ Sci Pollut Res 25(34):33867-33881

Barzman M, Bàrberi P, Birch ANE, Boonekamp P, Dachbrodt-Saaydeh S, Graf B, Hommel B, Jensen JE, Kiss J, Kudsk P, Lamichhane JR, Messéan A, Moonen AC, Ratnadass A, Rici P, Sarah JL, Sattin M (2015) Eight principles of integrated pest management. Agron Sustain Dev 35(4):1199-1215

Beckie HJ, Flower KC, Ashworth MB (2020) Farming without glyphosate? Plants 9(1):96

Benbrook CM (2019) How did the US EPA and IARC reach diametrically opposed conclusions on the genotoxicity of glyphosate-based herbicides? Environ Sci Eur 31(1):2

Bernhardt ES, Rosi EJ, Gessner MO (2017) Synthetic chemicals as agents of global change. Front Ecol Environ 15(2):84-90

Bojnec S̆, Fertő I (2019) European Union countries agri-food trade structures and main competitors on the internal and global agri-food markets. Econ Agric 66(2):635-650

Borsellino V, Schimmenti E, El Bilali H (2020) Agri-food markets towards sustainable patterns. Sustainability 12:2193

Boucaud-Maitre D, Rambourg MO, Sinno-Tellier S, Puskarczyk E, Pineau X, Kammerer M, Bloch J, Langrand J (2019) Human exposure to banned pesticides reported to the French Poison Control Centers: 2012-2016. Environ Toxicol Pharmacol 69:51-56

Bruce TJ, Smart LE, Birch ANE, Blok VC, MacKenzie K, Guerrieri E, Cascone P, Luna E, Ton J (2017) Prospects for plant defence activators and biocontrol in IPM-concepts and lessons learnt so far. Crop Prot 97:128-134

Chèze B, David M, Martinet V (2020) Understanding farmers' reluctance to reduce pesticide use: a choice experiment. Ecol Econ 167:106349

Chhipa H (2017) Nanofertilizers and nanopesticides for agriculture. Environ Chem Lett 15(1):15-22

Compant S, Duffy B, Nowak J, Clement C, Barka A (2005) Use of plant growth-promoting bacteria for biocontrol of plant diseases: principles, mechanisms of action, and future prospects. Appl Environ Microbiol 71(9):4951-4959

Crenna E, Jolliet O, Collina E, Sala S, Fantke P (2020) Characterizing honey bee exposure and effects from pesticides for chemical prioritization and life cycle assessment. Environ Int 138:105642

Cui S, Hough R, Yates K, Osprey M, Kerr C, Cooper P, Coul M, Zhang Z (2020) Effects of season and sediment-water exchange processes on the partitioning of pesticides in the catchment environment: Implications for pesticides monitoring. Sci Total Environ 698: 134228 
Czaja K, Struciński P, Korcz W, Minorczyk M, Hernik A, Wiadrowska B (2020) Alternative toxicological methods for establishing residue definitions applied for dietary risk assessment of pesticides in the European Union. Food Chem Toxicol 137:111120

Damalas CA, Abdollahzadeh G (2016) Farmers' use of personal protective equipment during handling of plant protection products: determinants of implementation. Sci Total Environ 571:730-736

Damalas CA, Koutroubas SD (2018) Farmers' behaviour in pesticide use: a key concept for improving environmental safety. Curr Opin Environ Sci Health 4:27-30

Dara SK (2019) The new integrated pest management paradigm for the modern age. J Integr Pest Manag 10(1):12

Dmowska E, Ilieva K (1995) The effect of prolonged diverse mineral fertilization on. Eur J Soil Biol 31(4):189-198

Dodds WK, Smith VH (2016) Nitrogen, phosphorus, and eutrophication in streams. Inland Waters 6(2):155-164

Dou M, Ma X, Zhang Y, Zhang Y, Shi Y (2019) Modeling the interaction of light and nutrients as factors driving lake eutrophication. Ecol Model 400:41-52

Egbuna C, Sawicka B, Tijjani H, Kryeziu TL, Ifemeje JC, Skiba D, Lukong CB (2020) Biopesticides, safety issues and market trends. In: Natural Remedies for Pest, Disease and Weed Control. Academic Press, pp 43-53

Feola G, Binder CR (2010) Why don't pesticide applicators protect themselves? Int J Occup Environ Health 16(1):11-23

Firlej K, Kowalska A, Piwowar A (2017) Competitiveness and innovation of the Polish food industry. Agric Econ (Agric Econ - Czech) 63:502-509

Fletcher SJ, Reeves PT, Hoang BT, Mitter N (2020) A perspective on RNAi-based biopesticides. Front Plant Sci 11:51

Fortunati E, Mazzaglia A, Balestra GM (2019) Sustainable control strategies for plant protection and food packaging sectors by natural substances and novel nanotechnological approaches. J Sci Food Agric 99(3):986-1000

Gagic V, Kleijn D, Báldi A, Boros G, Jørgensen HB, Elek Z, Garratt MPD, De Groot GA, Hedlund K, Kovacs-Hostyanszki A, Marini L, Martin E, Pevere I, Potts SG, Redlich S, Senapathi D, SteffanDewenter I, Switek S, Smith HG, Takacs V, Tryjanowski P, Van der Putten WH, Van Gils S, Bommarco R (2017) Combined effects of agrochemicals and ecosystem services on crop yield across Europe. Ecol Lett 20(11):1427-1436

Garrigou A, Laurent C, Berthet A, Colosio C, Jas N, Daubas-Letourneux V, Jackson Filho JM, Jouzel JN, Samuel O, Baldi I, Lebailly P, Galey L, Goutile F, Judon N (2020) Critical review of the role of PPE in the prevention of risks related to agricultural pesticide use. Saf Sci 123:104527

Han MA, Kim JH, Song HS (2019) Persistent organic pollutants, pesticides, and the risk of thyroid cancer: systematic review and metaanalysis. Eur J Cancer Prev 28(4):344-349

Harrison RD, Thierfelder C, Baudron F, Chinwada P, Midega C, Schaffner U, Van Den Berg J (2019) Agro-ecological options for fall armyworm (Spodoptera frugiperda JE Smith) management: providing low-cost, smallholder friendly solutions to an invasive pest. J Environ Manag 243:318-330

Hazra DK, Purkait A (2019) Role of pesticide formulations for sustainable crop protection and environment management: a review. J Pharmacogn Phytochem 8(2):686-693

Hedlund J, Longo SB, York R (2020) Agriculture, pesticide use, and economic development: a global examination (1990-2014). Rural Sociol 85(2):519-544

Herrero-Hernández E, Simón-Egea AB, Sánchez-Martín MJ, RodríguezCruz MS, Andrades MS (2020) Monitoring and environmental risk assessment of pesticide residues and some of their degradation products in natural waters of the Spanish vineyard region included in the denomination of origin jumilla. Environ Pollut:114666

Hladik ML, Vandever M, Smalling KL (2016) Exposure of native bees foraging in an agricultural landscape to current-use pesticides. Sci Total Environ 542:469-477

Huang W, He Y, Xiao J, Huang Y, Li A, He M, Wu K (2019) Risk of breast cancer and adipose tissue concentrations of polychlorinated biphenyls and organochlorine pesticides: a hospital-based case-control study in Chinese women. Environ Sci Pollut Res 26(31):32128 32136

Hvězdová M, Kosubová P, Košíková M, Scherr KE, Šimek Z, Brodský L, Šudoma M, Škulcová L, Sáňka M, Svobodová M, Krkošková L, Vašíčková J, Neuwirthová N, Bielská L, Hofman J (2018) Currently and recently used pesticides in Central European arable soils. Sci Total Environ 613:361-370

Isman MB (2020) Botanical insecticides in the twenty-first centuryfulfilling their promise? Annu Rev Entomol 65:233-249

Jallow MF, Awadh DG, Albaho MS, Devi VY, Thomas BM (2017) Pesticide risk behaviors and factors influencing pesticide use among farmers in Kuwait. Sci Total Environ 574:490-498

Jankowska M, Łozowicka B, Kaczyński P (2019) Comprehensive toxicological study over 160 processing factors of pesticides in selected fruit and vegetables after water, mechanical and thermal processing treatments and their application to human health risk assessment. Sci Total Environ 652:1156-1167

Jørgensen LN, Kudsk P, Ørum JE (2019) Links between pesticide use pattern and crop production in Denmark with special reference to winter wheat. Crop Prot 119:147-157

Karlsson Green K, Stenberg JA, Lankinen Å (2020) Making sense of Integrated Pest Management (IPM) in the light of evolution. Evol Appl 13(8):1791-1805

Kerr A, Bullard G (2020) Biocontrol of crown gall by Rhizobium rhizogenes: challenges in biopesticide Commercialisation. Agronomy 10(8):1126

Klich D, Łopucki R, Stachniuk A, Sporek M, Fornal E, Wojciechowska M, Olech W (2020) Pesticides and conservation of large ungulates: health risk to European bison from plant protection products as a result of crop depredation. PLoS One 15(1):e0228243

Kogan M (1998) Integrated pest management: historical perspectives and contemporary developments. Annu Rev Entomol 43(1):243-270

Kudsk P, Mathiassen SK (2020) Pesticide regulation in the European Union and the glyphosate controversy. Weed Sci 68(3):214-222

Kumar S, Nehra M, Dilbaghi N, Marrazza G, Hassan AA, Kim KH (2019) Nano-based smart pesticide formulations: Emerging opportunities for agriculture. J Control Release 294:131-153

Lamichhane JR, Dachbrodt-Saaydeh S, Kudsk P, Messéan A (2016) Toward a reduced reliance on conventional pesticides in European agriculture. Plant Dis 100(1):10-24

Lavik MS, Hardaker JB, Lien G, Berge TW (2020a) A multi-attribute decision analysis of pest management strategies for Norwegian crop farmers. Agric Syst 178:102741

Lavik MS, Lien G, Korsaeth A, Hardaker JB (2020b) Comparison of conventional and IPM cropping systems: a risk efficiency analysis. J Agric Appl Econ:1-13. https://doi.org/10.1017/aae.2020.8

Lechenet M, Dessaint F, Py G, Makowski D, Munier-Jolain N (2017) Reducing pesticide use while preserving crop productivity and profitability on arable farms. Nat Plants 3(3):1-6

Lee R, den Uyl R, Runhaar H (2019) Assessment of policy instruments for pesticide use reduction in Europe; learning from a systematic literature review. Crop Prot 126:104929 
Lefebvre M, Langrell SR, Gomez-y-Paloma S (2015) Incentives and policies for Integrated Pest Management in Europe: a review. Agron Sustain Dev 35(1):27-45. https://doi.org/10.1007/s13593014-0237-2

Leong WH, Teh SY, Hossain MM, Nadarajaw T, Zabidi-Hussin Z, Chin SY, Lai KS, Lim SHE (2020) Application, monitoring and adverse effects in pesticide use: the importance of reinforcement of good agricultural practices (GAPs). J Environ Manag 260:109987

Liu EM, Huang J (2013) Risk preferences and pesticide use by cotton farmers in China. J Dev Econ 103:202-215

Lopes T, Hatt S, Xu Q, Chen J, Liu Y, Francis F (2016) Wheat (Triticum aestivum L.)-based intercropping systems for biological pest control. Pest Manag Sci 72(12):2193-2202

Łozowska B, Kaczyński P, Rutkowska E, Jankowska M, Hrynko I (2013) Evaluation of pesticide residues in fruit from Poland and health risk assessment. Agric Sci 4(05):106

Ma W, Abdulai A (2019) IPM adoption, cooperative membership and farm economic performance. China Agric Econ Rev 11(2):218-236

Mancini F, Woodcock BA, Isaac NJ (2019) Agrochemicals in the wild: identifying links between pesticide use and declines of nontarget organisms. Curr Opin Environ Sci Health 11:53-58

Matthews GA (2008) Attitudes and behaviours regarding use of crop protection products-a survey of more than 8500 smallholders in 26 countries. Crop Prot 27(3-5):834-846

Means of production in agriculture in the 2018/19 farming year. Statistics Poland, Warsaw 2020 [In Polish].

Mekonnen Y, Agonafir T (2002) Pesticide sprayers' knowledge, attitude and practice of pesticide use on agricultural farms of Ethiopia. Occup Med 52(6):311-315

Mengistie BT, Mol AP, Oosterveer P (2017) Pesticide use practices among smallholder vegetable farmers in Ethiopian Central Rift Valley. Environ Dev Sustain 19(1):301-324

Möhring N, Bozzola M, Hirsch S, Finger R (2020a) Are pesticides risk decreasing? The relevance of pesticide indicator choice in empirical analysis. Agric Econ 51(3):429-444

Möhring N, Ingold K, Kudsk P, Martin-Laurent F, Niggli U, Siegrist M, Studer B, Walter A, Finger R (2020b) Pathways for advancing pesticide policies. Nat Food 1(9):535-540

Mondino P, González-Andújar JL (2019) Evaluation of a decision support system for crop protection in apple orchards. Comput Ind 107: 99-103

Moss S (2019) Integrated weed management (IWM): why are farmers reluctant to adopt non-chemical alternatives to herbicides? Pest Manag Sci 75(5):1205-1211

Myers JP, Antoniou MN, Blumberg B, Carroll L, Colborn T, Everett LG, Hansen M, Landrigan PJ, Lanphear BP, Mesnage R, Vandenberg LN, Vom Saal FS, Welshons WV, Benbrook CM (2016) Concerns over use of glyphosate-based herbicides and risks associated with exposures: a consensus statement. Environ Health 15(1):1-13

Narayan S, Liew Z, Bronstein JM, Ritz B (2017) Occupational pesticide use and Parkinson's disease in the Parkinson Environment Gene (PEG) study. Environ Int 107:266-273

Ndao A, Kumar LR, Tyagi RD, Valéro J (2020) Biopesticide and formulation processes based on starch industrial wastewater fortified with soybean medium. J Environ Sci Health B 55(2):115-126

Niewiadomska A, Sulewska H, Wolna-Maruwka A, Ratajczak K, Waraczewska Z, Budka A (2020) The influence of bio-stimulants and foliar fertilizers on yield, plant features, and the level of soil biochemical activity in white lupine (Lupinus albus L.) Cultivation. Agronomy 10:150

Padilla JT, Selim HM (2020) Environmental behavior of glyphosate in soils. In: Advances in Agronomy, vol 159. Academic Press, pp 1-34

Pavela R, Benelli G (2016) Essential oils as ecofriendly biopesticides? Challenges and constraints. Trends Plant Sci 21(12):1000-1007

Pimentel D, McLaughlin L, Zepp A, Lakitan B, Kraus T, Kleinman P, Vancini F, Roach J, Graap E, Keeton WS, Selig G (1993)
Environmental and economic effects of reducing pesticide use in agriculture. Agric Ecosyst Environ 46(1-4):273-288

Piwowar A (2018a) Chemiczna ochrona roślin we współczesnym rolnictwie w perspektywie ekonomicznej i ekologicznejkorzyści, koszty oraz preferencje. Wyd. Uniwersytetu Ekonomicznego we Wrocławiu, Wrocław [In Polish]

Piwowar A (2018b) The consumption of mineral fertilizers and herbicides in Poland against the background of the European Union. Probl World Agric 18(1):194-202. https://doi.org/10.22630/PRS. 2018.18.1.18

Piwowar A (2019) Low carbon agriculture in Poland - theoretical and practical challenges. Pol J Environ Stud 28(4):2785-2792. https:// doi.org/10.15244/pjoes/92211

Piwowar A (2020) Farming practices for reducing ammonia emissions in Polish agriculture. Atmosphere 11(12). https://doi.org/10.3390/ atmos11121353

Prado A, Pioz M, Vidau C, Requier F, Jury M, Crauser D, Brunet JL, Le Conte Y, Alaux C (2019) Exposure to pollen-bound pesticide mixtures induces longer-lived but less efficient honey bees. Sci Total Environ 650:1250-1260

Rogacz D, Lewkowski J, Cal D, Rychter P (2020) Ecotoxicological effects of new C-substituted derivatives of $\mathrm{N}$ phosphonomethylglycine (glyphosate) and their preliminary evaluation towards herbicidal application in agriculture. Ecotoxicol Environ Saf 194:110331

Rolnictwo i gospodarka żywnościowa w Polsce. Ministerstwo Rolnictwa i Rozwoju Wsi, Warszawa 2019 [In Polish]

Rynek środków produkcji dla rolnictwa. Analizy Rynkowe 2019, 46, 25 [In Polish]

Sabarwal A, Kumar K, Singh RP (2018) Hazardous effects of chemical pesticides on human health-Cancer and other associated disorders. Environ Toxicol Pharmacol 63:103-114

Schäfer RB, Caquet T, Siimes K, Mueller R, Lagadic L, Liess M (2007) Effects of pesticides on community structure and ecosystem functions in agricultural streams of three biogeographical regions in Europe. Sci Total Environ 382(2-3):272-285

Scown M, Nicholas K (2020) European agricultural policy requires a stronger performance framework to achieve the Sustainable Development Goals. Global Sustain 3:E11. https://doi.org/10. $1017 /$ sus.2020.5

Serrano E, Munoz M, de Pedro ZM, Casas JA (2020) Fast oxidation of the neonicotinoid pesticides listed in the EU Decision 2018/840 from aqueous solutions. Sep Purif Technol 235:116168

Silva V, Montanarella L, Jones A, Fernández-Ugalde O, Mol HG, Ritsema CJ, Geissen V (2018) Distribution of glyphosate and aminomethylphosphonic acid (AMPA) in agricultural topsoils of the European Union. Sci Total Environ 621:1352-1359

Silva V, Mol HG, Zomer P, Tienstra M, Ritsema CJ, Geissen V (2019) Pesticide residues in European agricultural soils-a hidden reality unfolded. Sci Total Environ 653:1532-1545

Slattery M, Harper B, Harper S (2019) Pesticide encapsulation at the nanoscale drives changes to the hydrophobic partitioning and toxicity of an active ingredient. Nanomaterials 9(1):81

Southon RJ, Fernandes OA, Nascimento FS, Sumner S (2019) Social wasps are effective biocontrol agents of key lepidopteran crop pests. Proc R Soc B 286(1914):20191676

Stenberg JA (2017) A conceptual framework for integrated pest management. Trends Plant Sci 22(9):759-769

Svobodová Z, Skoková Habuštová O, Spitzer L, Sehnal F (2020) Importance of functional classification in the use of carabids for the environmental risk assessment of the GE crops and other agricultural practices. Insect Sci 27(2):375-388

Świergiel W, Manduric S, Rämert B, Porcel M, Tasin M (2019) Development of sustainable plant protection programs through multi-actor co-innovation: An 8-year case study in Swedish apple production. J Clean Prod 234:1178-1191 
Székács A, Mörtl M, Darvas B (2015) Monitoring pesticide residues in surface and ground water in Hungary: surveys in 1990-2015. J Chem 717948. https://doi.org/10.1155/2015/717948

Szelag-Sikora A, Sikora J, Niemiec M, Gródek-Szostak Z, Kapusta-Duch J, Kuboń M, Komorowska M, Karcz J (2019) Impact of integrated and conventional plant production on selected soil parameters in carrot production. Sustainability 11(20):5612

Szpyrka E, Slowik-Borowiec M, Matyaszek A, Podbielska M, Rupar J (2016) Pesticide residues in raw agricultural products from the south-eastern region of Poland and the acute risk assessment. Ann Natl Inst Hyg 67(3):237-245

Tayour C, Ritz B, Langholz B, Mills PK, Wu A, Wilson JP, Shahabi K, Cockburn M (2019) A case-control study of breast cancer risk and ambient exposure to pesticides. Environ Epidemiol 3(5):e070

Treder K, Jastrzębska M, Kostrzewska MK, Makowski P (2020) Do long-term continuous cropping and pesticides affect earthworm communities? Agronomy 10:586

Uhl P, Brühl CA (2019) The impact of pesticides on flower-visiting insects: a review with regard to European risk assessment. Environ Toxicol Chem 38(11):2355-2370

Vašíčková J, Hvězdová M, Kosubová P, Hofman J (2019) Ecological risk assessment of pesticide residues in arable soils of the Czech Republic. Chemosphere 216:479-487

Vasileiadis VP, Moonen AC, Sattin M, Otto S, Pons X, Kudsk P, Pelzer E (2013) Sustainability of European maize-based cropping systems: economic, environmental and social assessment of current and proposed innovative IPM-based systems. Eur J Agron 48:1-11

Wang S, Wang J, Wang T, Li C, Wu Z (2019) Effects of ozone treatment on pesticide residues in food: a review. Int J Food Sci Technol 54(2): 301-312
Włodarczyk M, Siwek H (2017) The influence of humidity and soil texture on the degradation process of selected herbicides immobilized in alginiate matrix in soil under laboratory conditions. Polish J Soil Sci XL(1):121-130

Woodcock BA, Bullock JM, Shore RF, Heard MS, Pereira MG, Redhead J, Ridding L, Dean H, Sleep D, Henrys P, Peyton J, Hulmes S, Hulmes L, Sárospataki M, Saure C, Edwards M, Genersch E, Knäbe S, Pywell RF (2017) Country-specific effects of neonicotinoid pesticides on honey bees and wild bees. Science 356(6345):1393-1395

Yan JJ, Sarkar SC, Meng RX, Reitz S, Gao YL (2020) Potential of Steinernema carpocapsae (Weiser) as a biological control agent against potato tuber moth, Phthorimaea operculella (Zeller)(Lepidoptera: Gelechiidae). J Integr Agric 19(2):389-393

Zarzecka K, Gugała M, Grzywacz K, Sikorska A (2020) Agricultural and economic effects of the use of biostimulants and herbicides in cultivation of the table potato cultivar Gawin. Acta Sci Pol Agric 19(1): 3-10. https://doi.org/10.37660/aspagr.2020.19.1.1

Zawiślak J, Adamczyk J, Johnson DR, Lorenz G, Black J, Hornsby Q, Stewart SD, Joshi N (2019) Comprehensive survey of area-wide agricultural pesticide use in Southern United States row crops and potential impact on honey bee colonies. Insects 10:280

Zeng F, Lerro C, Lavoué J, Huang H, Siemiatycki J, Zhao N, Ma S, Deziel NC, Friesen MC, Udelsman R, Zhang Y (2017) Occupational exposure to pesticides and other biocides and risk of thyroid cancer. Occup Environ Med 74(7):502-510

Publisher's note Springer Nature remains neutral with regard to jurisdictional claims in published maps and institutional affiliations. 